\title{
Kamrai tachycardiát okozó primer szív lymphoma
}

\section{Primary cardiac lymphoma presenting as ventricular tachycardia}

\author{
Nagy Beáta ${ }^{1}$, Timár Botond ${ }^{1}$, Mikala Gábor ${ }^{2}$, Ceglédi Andrea ${ }^{2}$, Czimbalmos Csilla $^{3}$, \\ Szabó Péter ${ }^{4}$, Fintha Attila ${ }^{1,}$ \\ ${ }^{1}$ Semmelweis Egyetem, I. sz. Patológiai és Kísérleti Rákkutató Intézet, Budapest \\ ${ }^{2}$ Dél-pesti Centrumkórház - Országos Hematológiai és Infektológiai Intézet, Budapest \\ ${ }^{3}$ Semmelweis Egyetem Városmajori Szív- és Érgyógyászati Klinika, Budapest \\ ${ }^{4}$ ScanoMed Kft., PET-CT Központ, Budapest
}

(Beérkezett: 2020. március 1.; elfogadva: 2020. május 22.)

\begin{abstract}
A disszeminált lymphoproliferatív megbetegedésekben közel 25\%-ban fordul elő másodlagos szív érintettség. Ezzel szemben a primer lymphomák a szív daganatainak kevesebb mint 1\%-át adják [1]. Utóbbi egy vagy több gócú, intramuralis térfoglaló folyamat, mely többnyire a jobb szívfelet érinti. Szubtípusát tekintve leggyakoribb a magas malignitású B-sejtes lymphomák közé tartozó diffúz nagy B-sejtes lymphoma, de leírtak már Burkitt-lymphomát és néhány indolens, alacsony malignitású lymphomát is ebben a lokalizációban [2]. Az elváltozás immunkompetens és immunhiányos emberekben (AIDS, transzplantáció, autoimmun-megbetegedések kezelésére használt immunszuppresszió) is megjelenhet, és a páciensek kivizsgálásakor gondolni kell az EBV-asszociált lymphoproliferatív megbetegedések lehetőségére is.

$\mathrm{Az} 55$ éves férfi kivizsgálása kamrai tachycardia miatt kezdődött. Az elsődlegesen elvégzett koszorúérfestés érszükületet nem mutatott, az echocardiographiás vizsgálat során jó szívfunkció igazolódott, falmozgászavar nem volt. A Holter-monitoron nem tartós kamrai tachycardia jelentkezett. Az elektrocardiogram többször széles QRS tachycardiát mutatott, mely panaszt nem okozott. A további
\end{abstract}

vizsgálatok során a szív-MR-felvételeken jó bal kamrai pumpafunkció mellett, strukturális eltérésként a jobb koszorúeret körbefogó, jól vascularisalt térfoglalás volt látható a jobb kamra szabad fala mentén és az atrioventricularis árokban.

Az elváltozás pontos szöveti meghatározása céljából corebiopsziás mintavétel történt, amelyben szívizomszövetet destruáló, diffúz megjelenésü, nagy lymphoid sejtekből, elsősorban centroblastokból álló tumor infiltrátuma volt látható. Immunhisztokémiai vizsgálattal a nagy sejtek CD20, Bcl-2, Bcl-6 és CD10 expressziót mutattak és MUM-1-negatívak voltak. Ki-67-tel a proliferációs aktivitás $70 \%$ körüli volt (1. ábra). CD3-ellenes antitesttel a reaktív kis T-sejtek jelölődtek. CD21 elleni antitesttel egy-egy pozitív sejten kívül follicularis dendritikus sejtes hálózatot nem azonosítottunk. FISH-vizsgálattal a $B C L-2$ gén törése igazolódott, de a $B C L-6$ és $C-M Y C$ gének vad típusúak voltak, ami alapján „double hit” lymphoma kizárható. Összességében a folyamat diffúz nagy B-sejtes lymphomának (DLBCL) felel meg, centrum germinatívum (GC) fenotípussal.

\footnotetext{
@ Levelezési cím: Dr. Fintha Attila, Semmelweis Egyetem, I. sz. Patológiai és Kísérleti Rákkutató Intézet, 1085 Budapest, Üllői út 26. E-mail: fintha.attila@med.semmelweis-univ.hu
} 

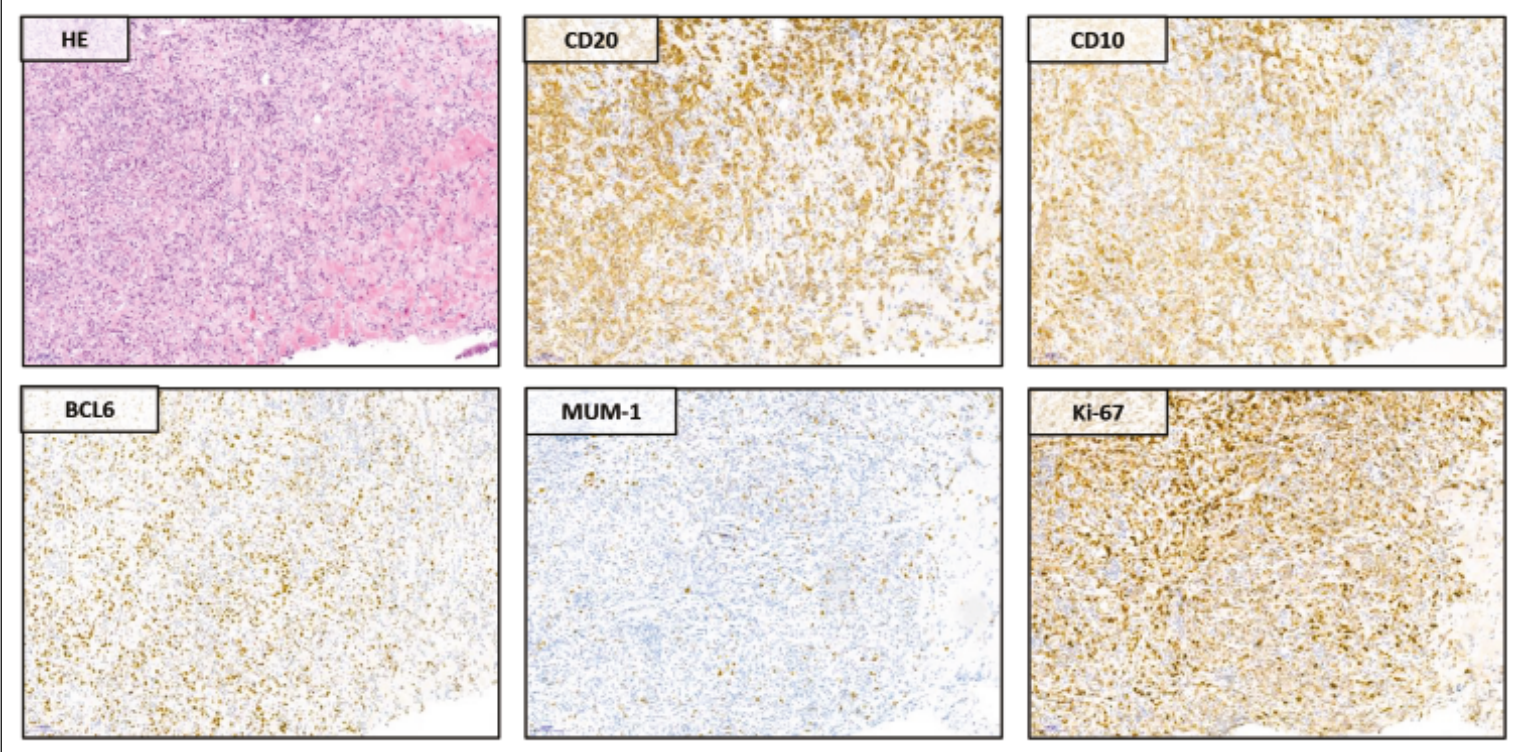

1. ábra. A jobb kamrai tumorból vett szövettani minta HE-festett mikroszkópos képe és immunhisztokémiai profilja (12× nagyítás)

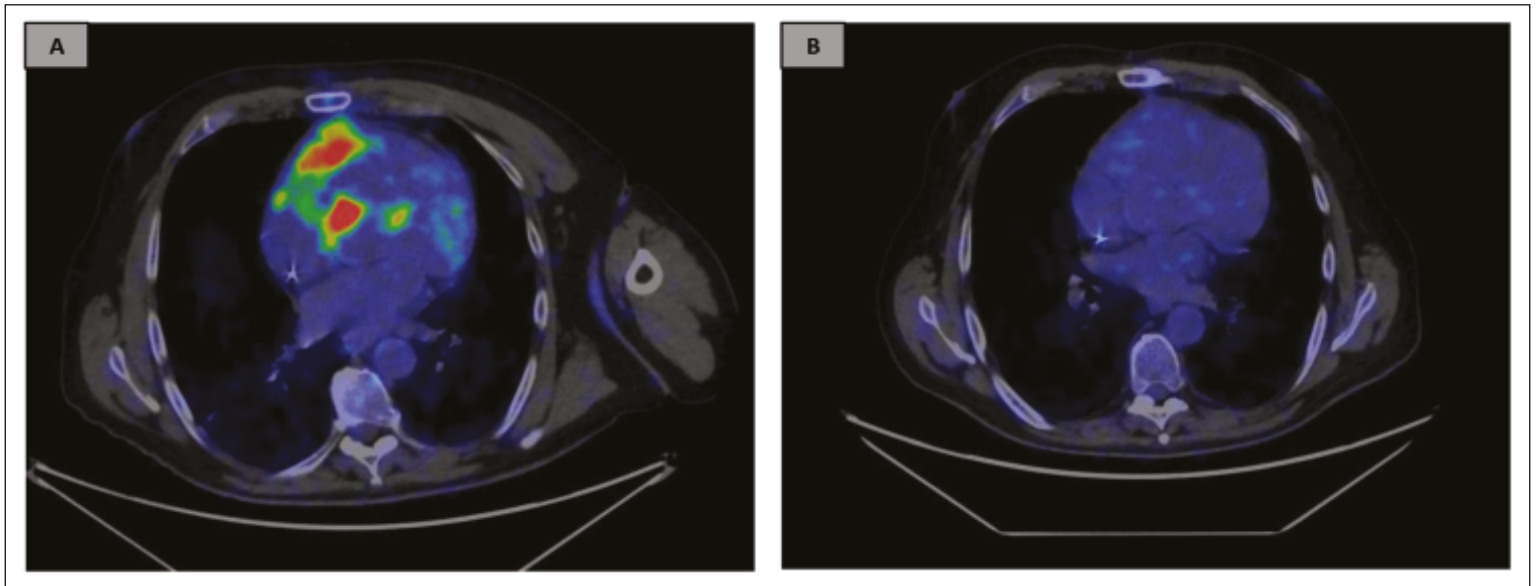

2. ábra. A beteg diagnóziskori (A) és 11 hónappal később, kezelés után készült kontroll PET/CT-felvételét (B) összehasonlítva morfo-metabolikus remisszió látható

A staging PET/CT-felvételeken a cardialis lokalizáció mellett egy mediastinalis és inguinalis nyirokcsomó is FDG-halmozást mutatott, azonban ezek egyértelmü lymphomás érintettsége nem igazolódott.

A primer szív lymphoma többnyire szívelégtelenség, mellkasi fájdalom vagy aritmia tüneteivel jelentkezik, de az esetek egy részében tünetmentes is lehet, mely megnehezíti a betegség korai felismerését [3]. Ha a panaszok hátterében nem igazolódik coronariabetegség, gondolni kell esetleges térfoglaló folyamat fennállására is. Ilyenkor segítheti a diagnózist a transthoracalis echocardiographia, a szív-MR-vizsgálat, vagy amennyiben tisztázatlan marad a mellkasi panaszok etiológiája, érdemes megfontolni a biopsziás mintavétel lehetőségét is. A mihamarabbi pontos diagnózis rendkívül fontos a megfelelő kemoterápiás kezelés megkezdéséhez. A többi szívdaganattal ellentétben, melyek mútéti eltávolítása gyakran kuratív, a lymphoid megbetegedések kezelésére a cyclophosphamid, doxorubicin, vincristin, prednison (CHOP) kombináció alkalmas, amelyet CD20 pozitív entitásoknál addicionálisan rituximab immunoterápia és néhány esetben radioterápia egészít ki. Esetünkben a beteg jelenleg túl van 6 ciklus R-CHOP-kezelésen, és reziduális tumorszövet miatt R-GemOx-terápiában is részesült. 11 hónappal a diagnózist követően PET/CT kontrollvizsgálattal igazolt morfo-metabolikus remissziót ért el (2. ábra). Jelenleg az elért remissziót konszolidáló nagydózisú kemoterápiát követő autológ őssejtátültetése tervezett. A primer és a secunder szív lymphoma prognózisa irodalmi adatok szerint rossz, a betegek átlagos túlélése a terápiás erőfeszítések ellenére mindössze 12 hónap [1]. Reményeink szerint betegünk fenntartja elért komplett remisszióját és hosszú távú túlélő lesz. 
Nyilatkozat: A kézirat korábban más folyóiratban nem jelent meg, és máshova beküldésre nem került. A kézirat végleges változatát minden szerző elolvasta és jóváhagyta Érdekeltségek: A szerzőknek nincsenek a közleményhez kapcsolódó közvetlen érdekeltségeik.

Anyagi támogatás: A szerzők anyagi támogatásban nem részesültek.

Szerzői munkamegosztás: N.B., T.B., M.G., C.Cs., F.A. a kézirat elkészítése; N.B., Sz.P. - az ábraanyag képeinek összeállítása.

\section{Irodalom}

[1] Jeudy J., Burke A. P., Frazier A. A. Cardiac Lymphoma. Radiol Clin N Am. 2016; 54: 689-710.

[2] Gruver A. M., Huba M. A., Dogan A. et al. Fibrin-associated large B-cell lymphoma. Am J Surg Pathol. 2012; 36: 1527-1537.

[3] Gordon M. J., Danilova O., Spurgeon S. et al. Cardiac non-Hodgkin's lymphoma: clinical characteristics and trends in survival. 2016; 97(5): 445-452.

A cikk a Creative Commons Attribution 4.0 International License (https://creativecommons.org/licenses/by/4.0/) feltételei szerint publikált Open Access közlemény, melynek szellemében a cikk bármilyen médiumban szabadon felhasználható, megosztható és újraközölhető, feltéve, hogy az eredeti szerző és a közlés helye, illetve a CC License linkje és az esetlegesen végrehajtott módosítások feltüntetésre kerülnek. (SID_1) 